\title{
PEMODELAN KEBISINGAN LALULINTAS DI JALAN TERUSAN KOPO BANDUNG
}

\author{
Nyayu Luthfia Sya'bani ${ }^{1}$, Budi Hartanto Susilo ${ }^{2}$ \\ ${ }^{1}$ Alumnus S1, Jurusan Teknik Sipil, Universitas Kristen Maranatha \\ ${ }^{2}$ Guru Besar, Jurusan Teknik Sipil, Universitas Kristen Maranatha \\ JL. Prof. drg. Suria Sumantri, no. 65 Bandung 40164 \\ Email: budiharsus@yahoo.com
}

\begin{abstract}
ABSTRAK
SDN Angkasa V Lanud Sulaiman yang terletak pada tepi ruas Jalan Terusan Kopo yang merupakan akses menuju kawasan industri. Dengan begitu arus lalulintas di ruas jalan tersebut meningkat yang menimbulkan kebisingan pada lokasi pendidikan tersebut. Studi ini bertujuan untuk menghitung volume lalulintas, kecepatan rata - rata lalulintas, tingkat kebisingan lalulintas dan membuat model kebisingan lalulintas. Metode yang dilakukan dalam penelitian adalah dengan survei langsung di lapangan dan untuk menganalisis pemodelan kebisingan lalulintas menggunakan analisis regresi linier berganda dengan bantuan software SPSS (statistical package of the social sciences) versi 17.0. Dari hasil studi diperoleh bahwa pada Jalan Terusan Kopo volume lalulintas yang terjadi pagi hari sebesar 3322,35 smp/jam, pada siang hari sebesar 2596,7 $\mathrm{smp} / \mathrm{jam}$ dan pada sore hari sebesar $2864,9 \mathrm{smp} / \mathrm{jam}$. Untuk kecepatan rata-rata lalulintas yang terjadi adalah 36,00-51,50 km/jam untuk sepeda motor (MC), 31,00-45,00 km/jam untuk kendaraan ringan (LV) dan 31,00-39,00 km/jam untuk kendaraan berat (HV). Kebisingan lalulintas yang terjadi selama pengamatan adalah berkisar 78,50-80,80 $\mathrm{dB}(\mathrm{A})$. Kebisingan yang terjadi melebihi ambang batas yang dikeluarkan oleh Keputusan Kementrian Negara Lingkungan Hidup tahun 1996 yaitu 55 dB(A) untuk lokasi pendidikan dan U.S. Department of Transportation yaitu tidak melebihi $65 \mathrm{~dB}(\mathrm{~A})$. Pemodelan kebisingan lalulintas yang lebih baik dan logis merupakan hasil stepwise method, dimana yang berpengaruh paling besar terhadap kebisingan lalulintas adalah volume sepeda motor sebesar $70,4 \%$.
\end{abstract}

Kata kunci: kebisingan, kecepatan, volume, regresi linier, lalulintas, SPSS.

\begin{abstract}
SDN Angkasa V Lanud Sulaiman located on JL.Terusan Kopo which is the access to the industrial area. So, the traffic flow on the road increased which raises the noise at the education area. This study aimed to calculate the traffic volume, the traffic speed average, traffic noise levels and traffic noise modeling. The method is performed in this study are to survey in the location and to analyze the traffic noise modeling using multiple linear regression analysis that help by SPSS software (statistical package of the social sciences) version 17.0. The results obtained from studies on JL.Terusan Kopo the traffic volume that occurs in the morning of 3322,35 smp/hour, at noon of 2596,7 smp/h and in the afternoon of 2864,9 smp/hour. The traffic speed average that occurs is 36,00 51,50 km/h for motorcycles (MC), 31,00-45,00 km/h for light vehicles (LV) and 31,00-39,00 km/h for heavy vehicles (HV). Traffic noise that occurs during the observation is in the range 78,50-80,80 $\mathrm{dB}(\mathrm{A})$, that exceeds the threshold issued by the Ministry of Environment in 1996 is $55 \mathrm{~dB}(\mathrm{~A})$ for the education area and the U.S. Department of Transportation that does not exceed $65 \mathrm{~dB}(\mathrm{~A})$. The result of traffic noise modeling which are better and logical is from stepwise method, where 70,4\% volume of motorcycle had the greatest influence on traffic noise.
\end{abstract}

Keywords: Noise, speed, volume, linear regression, traffic, SPSS.

Pemodelan Kebisingan Lalulintas Di Jalan Terusan Kopo Bandung 


\section{PENDAHULUAN}

SDN Angkasa V Lanud Sulaiman merupakan salah satu lokasi pendidikan dimana tempat berlangsungnya kegiatan belajar mengajar yang terletak di tepi ruas jalan Terusan Kopo. Dengan berada di tepi ruas jalan Terusan Kopo memiliki kelebihan yaitu para pelajar mendapat akses keluar masuk dengan mudah. Namun demikian, adapun dampak negatif terhadap proses belajar mengajar karena ruang kelas yang terletak pada tepi ruas jalan Terusan Kopo yang merupakan akses menuju kawasan industry, dengan begitu arus lalulintas di ruas jalan tersebut meningkat yang menimbulkan kebisingan pada lokasi pendidikan tersebut.

Tujuan dari penelitian ini adalah menghitung volume lalulintas, kecepatan ratarata lalulintas, mengukur tingkat kebisingan lalulintas dan pemodelan kebisingan lalulintas di Jalan Terusan Kopo Bandung.

Ruang Lingkup penelitian sebagai berikut:

1. Lokasi penelitian adalah SDN Angkasa V Lanud Sulaiman yang terletak di jalan Terusan Kopo Km 10, Kabupaten Bandung.

2. Mengukur kebisingan lalu lintas pada lokasi penelitian dengan menggunakan alat Sound Level Meter (SLM).

3. Menghitung volume lalu lintas dan kecepatan kendaraan yang melewati lokasi penelitian. Jenis kendaraan yang diteliti adalah sepeda motor, kendaraan ringan (mobil penumpang) dan kendaraan berat (bus dan truk).

\section{TINJAUAN PUSTAKA}

\subsection{Volume Lalulintas}

Volume didefinisikan sebagai sebagai jumlah kendaraan yang melewati suatu titik pengamatan atau ruas jalan dengan suatu satuan waktu pada setiap periode yang dipilih. Pada umumnya besarnya volume selalu dinyatakan dalam jumlah kendaraan per interval waktu, yang biasanya diambil dalam jam.

Volume lalulintas terdiri dari berbagai jenis kendaraan dalam MKJI 1997 kendaraan dibagi menjadi empat jenis yaitu kendaraan berat (HV), kendaraan ringan (LV), sepeda motor (MC), kendaraan tidak bermotor (UM).

Untuk menyamakan satuan tiap jenis kendaraan yang berbeda kepada satu jenis kendaraan standar yaitu kendaraan penumpang, maka digunakan suatu satuan yang dinamakan SMP (satuan mobil penumpang). Secara umum rumus smp dapat ditunjukkan oleh persamaan:

$$
\text { smp }=\sum Q_{i} \cdot e m p
$$


dengan $\mathrm{Q}_{\mathrm{i}}=$ volume kendaraan $\mathrm{i}$.

\subsection{Kecepatan lalulintas}

Kecepatan lalulintas adalah jarak yang ditempuh suatu kendaraan untuk melewati ruas jalan tertentu per satuan waktu. Kecepatan dapat dinyatakan dengan satuan m/detik atau $\mathrm{km} / \mathrm{jam}$. Secara umum kecepatan dihitung dengan persamaan:

$$
u=\frac{d}{t}
$$

Keterangan:

$\mathrm{u}=$ kecepatan $(\mathrm{km} / \mathrm{jam})$

$\mathrm{d}=$ jarak yang ditempuh $(\mathrm{km})$

$\mathrm{t}=$ waktu untuk menempuh jarak yang ditempuh $d(\mathrm{jam})$

Susilo (Susilo, 2010) menyatakan bahwa kecepatan dipengaruhi oleh karakteristik geometrik, kondisi lalulintas, waktu, tempat, lingkungan dan pengemudi.

\subsection{Kebisingan}

Kebisingan adalah bunyi yang tidak diinginkan oleh telinga manusia yang ditimbulkan dari usaha atau kegiatan tertentu dalam periode waktu tertentu yang dapat mengganggu kenyamanan dan kesehatan manusia. Dalam hal ini kebisingan yang ditimbulkan adalah akibat kegiatan dari lalulintas yang berasal dari kendaraan yang melintas disuatu ruas jalan.

Keputusan Kementerian Negara Lingkungan Hidup Nomor KEP-48/MEN LH/11/1996 dalam pasal 1 disebutkan bahwa kebisingan adalah bunyi yang tidak diinginkan dari usaha atau kegiatan dalam tingkat dan waktu tertentu yang dapat menimbulkan gangguan kesehatan manusia dan kenyamanan manusia. Untuk baku mutu tingkat kebisingan pada suatu lingkungan mengacu pada KMLH 1996 dapat dilihat pada Tabel 1, sedangkan tingkat kebisingan yang juga direkomendasikan oleh U.S. Department of Housing and Urban Developtment dapat dilihat pada Tabel 2.

Pemodelan Kebisingan Lalulintas Di Jalan Terusan Kopo Bandung 
Tabel 1. Baku Mutu Tingkat Kebisingan

\begin{tabular}{|c|c|c|}
\hline \multicolumn{2}{|c|}{ Peruntukan kawasan/ lingkungan kesehatan } & $\begin{array}{c}\text { Tingkat kebisingan } \\
\text { dB(A) }\end{array}$ \\
\hline \multirow{4}{*}{ Peruntukan } & a. Perumahan dan pemukiman & 55 \\
& b. Perdagangan dan jasa & 70 \\
kawasan & c. Perkotaan dan perdagangan & 65 \\
& d. Ruang terbuka hijau & 50 \\
& e. Industri & 70 \\
& f. Pemerintahan dan fasilitas umum & 60 \\
& g. Rekreasi & 70 \\
\hline Lingkup & a. Rumah sakit dan sejenisnya & 55 \\
kegiatan & b. Sekolah atau sejenisnya & 55 \\
& c. Tempat ibadah atau sejenisnya & \\
\hline
\end{tabular}

Sumber: Kementerian Negara Lingkungan Hidup, 1996

Tabel 2. Tingkat Kebisingan Umum

\begin{tabular}{|c|}
\hline $\begin{array}{l}\text { Tingkat Kebisingan Umum } \\
\mathrm{dB}(\mathrm{A})\end{array}$ \\
\hline Tidak dapat diterima : \\
\hline Melebihi $80 \mathrm{~dB}(\mathrm{~A}), 60$ menit dalam 24 jam \\
\hline Melebihi $75 \mathrm{~dB}(\mathrm{~A}), 8$ jam dalam 24 jam \\
\hline Dapat dipilih atau tidak - biasanya tidak dapat diterima : \\
\hline Melebihi $65 \mathrm{~dB}(\mathrm{~A}), 8$ jam dalam 24 jam \\
\hline Suara - suara kuat yang berulang - ulang pada lokasi \\
\hline Dapat dipilih atau tidak - biasanya dapat diterima : \\
\hline Tidak melebihi $65 \mathrm{~dB}(\mathrm{~A})$, lebih dari 8 jam dalam 24 jam \\
\hline Dapat diterima : \\
\hline Tidak melebihi $45 \mathrm{~dB}(\mathrm{~A})$, lebih dari 30 menit dalam 24 jam \\
\hline
\end{tabular}

Sumber: U.S. Department of Transportation (1972) dalam Sistem Transportasi

(Susilo, B.H., 1998, hal 31)

\section{METODE PENELITIAN}

\subsection{Program Rencana Kerja}

Dalam penyusunan suatu penelitian diperlukan program rencana kerja yang dituangkan ke dalam sebuah bagan alir (Flow Chart). Bagan alir tersebut dibuat sebagai pedoman atau acuan sehingga penelitian dapat berjalan lancar dan memperoleh hasil yang 
optimal. Pada bagan alir penelitian dijelaskan tahapan-tahapan rencana kerja dari awal perencanan hingga pembahasan akhir yang dapat dilihat pada Gambar 1.

\subsection{Identifikasi Masalah dan Tujuan}

Dengan semakin bertambahnya volume kendaraan yang melewati ruas-ruas jalan berdampak kepada meningkatnya kebisingan lalulintas pada lingkungan di sekitar ruas jalan yang dilewati kendaraan-kendaraan tersebut; seperti lokasi pendidikan yang berada di tepi ruas jalan. Akibatnya adalah kebisingan lalulintas melebihi batas ambang baku yang ditetapkan dalam Keputusan Kementerian Negara Lingkungan Hidup Nomor KEP48/MEN LH/11/1996. Oleh karena itu diperlukan penelitian tingkat kebisingan yang dipengaruhi oleh arus lalulintas yang kemudian dibuat model kebisingannya yang dapat digunakan untuk memprediksi.

\subsection{Lokasi Penelitian}

Lokasi penelitian dilakukan di depan SDN Angkasa V yang berada di tepi ruas jalan Terusan Kopo Bandung. Lokasi ini dipilih karena ruang kelas berada di dekat ruas jalan Terusan kopo yang merupakan akses ke kawasan industri sehingga berbagai jenis kendaraan melintas di ruas jalan tersebut. Dengan berbagai jenis kendaraan yang melintas maka kebisingan di daerah tersebut tinggi. Adapun lokasi dan denah situasi penelitian yang di survei dapat dilihat pada Gambar 2. 


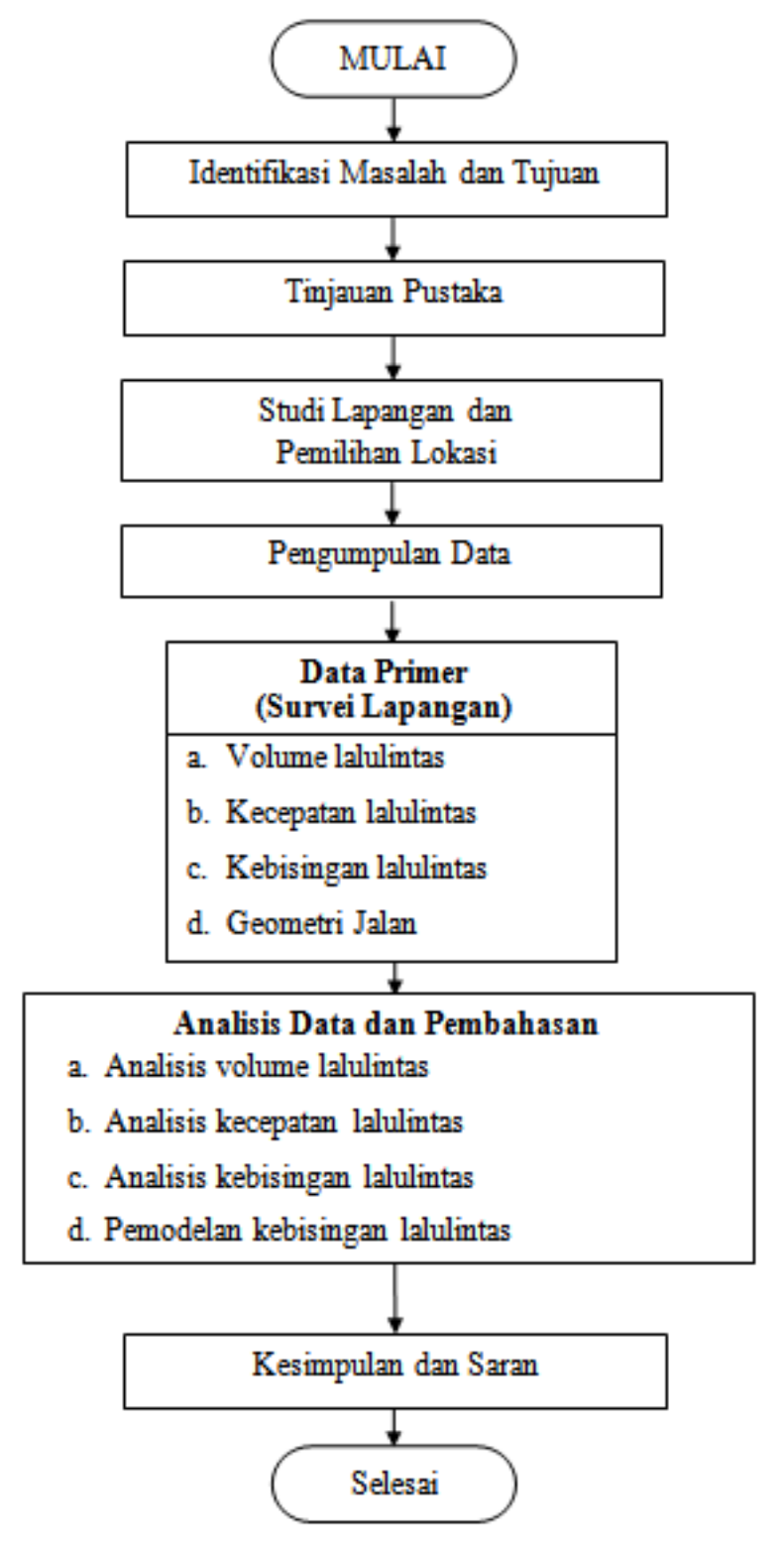

Gambar 1. Bagan Alir Penelitian 


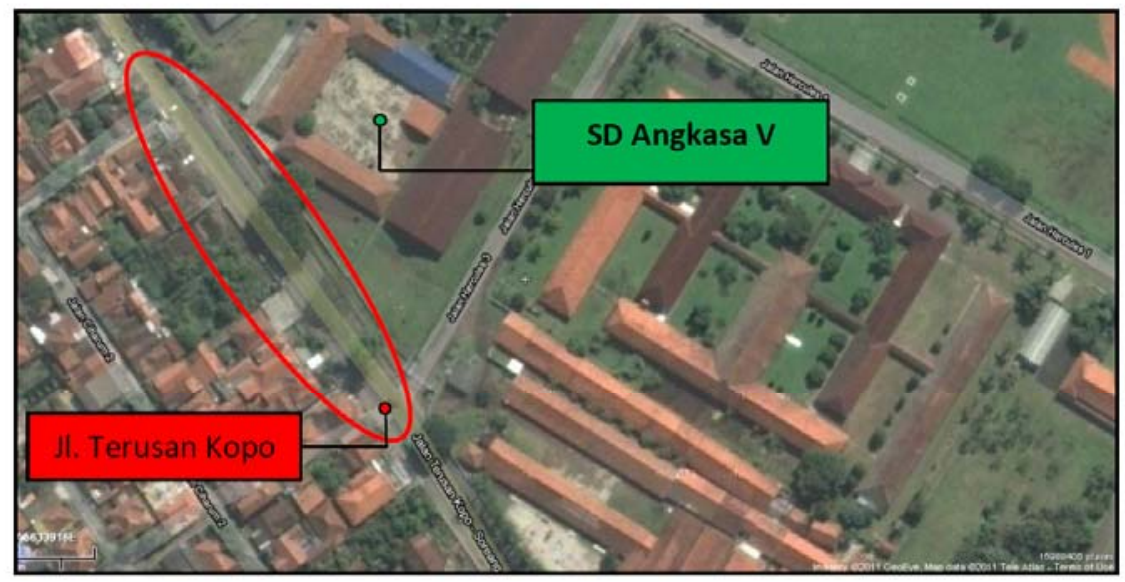

Keterangan :

- lokasi penelitian

Sumber: Google Earth

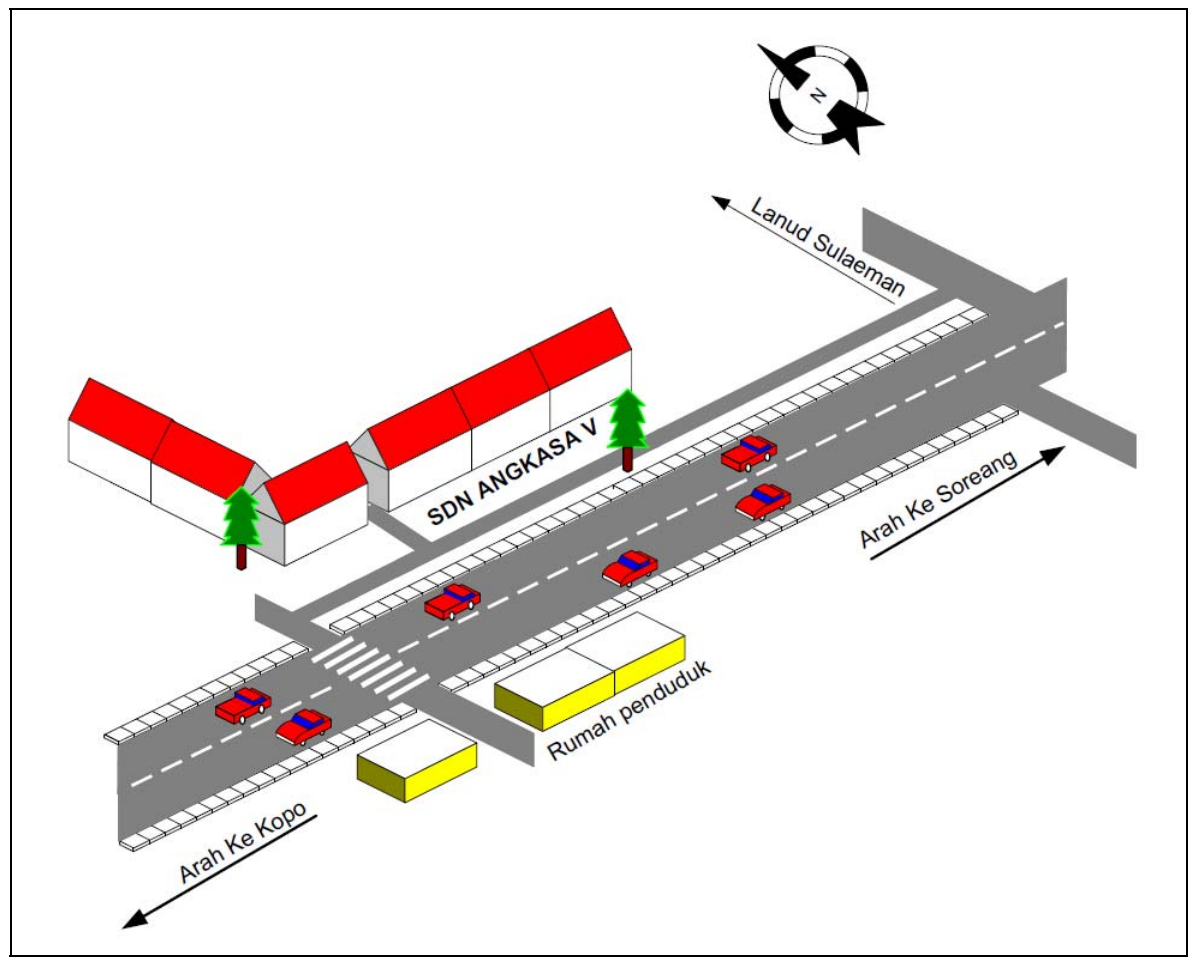

Gambar 2. Lokasi Penelitian Daerah Jalan Terusan Kopo Bandung dan Denah Situasi Sekitar SDN Angkasa V 


\section{ANALISIS DATA DAN PEMBAHASAN}

\subsection{Analisis Volume Lalulintas}

Volume lalulintas merupakan dasar yang digunakan dalam analisis lalulintas. Oleh karena itu variasi volume yang ada tiap jam sangat penting untuk melihat fluktuasi yang terjadi. Untuk menyamakan satuan tiap jenis kendaraan yang berbeda kepada satuan kendaraan standar, maka digunakan suatu satuan yang dinamakan satuan mobil penumpang (smp). Nilai smp diperoleh dengan mengalikan jumlah suatu jenis kendaraan dengan dengan nilai emp.

Untuk menyamakan satuan tiap jenis kendaraan yang berbeda kepada satuan kendaraan standar, maka digunakan suatu satuan yang dinamakan satuan mobil penumpang (smp). Nilai smp diperoleh dengan mengalikan jumlah suatu jenis kendaraan dengan dengan nilai emp. Untuk mempermudah melihat fluktuasi volume lalulintas di Jalan Terusan Kopo maka dibuat grafik berdasarkan data nilai smp volume lalulintas.

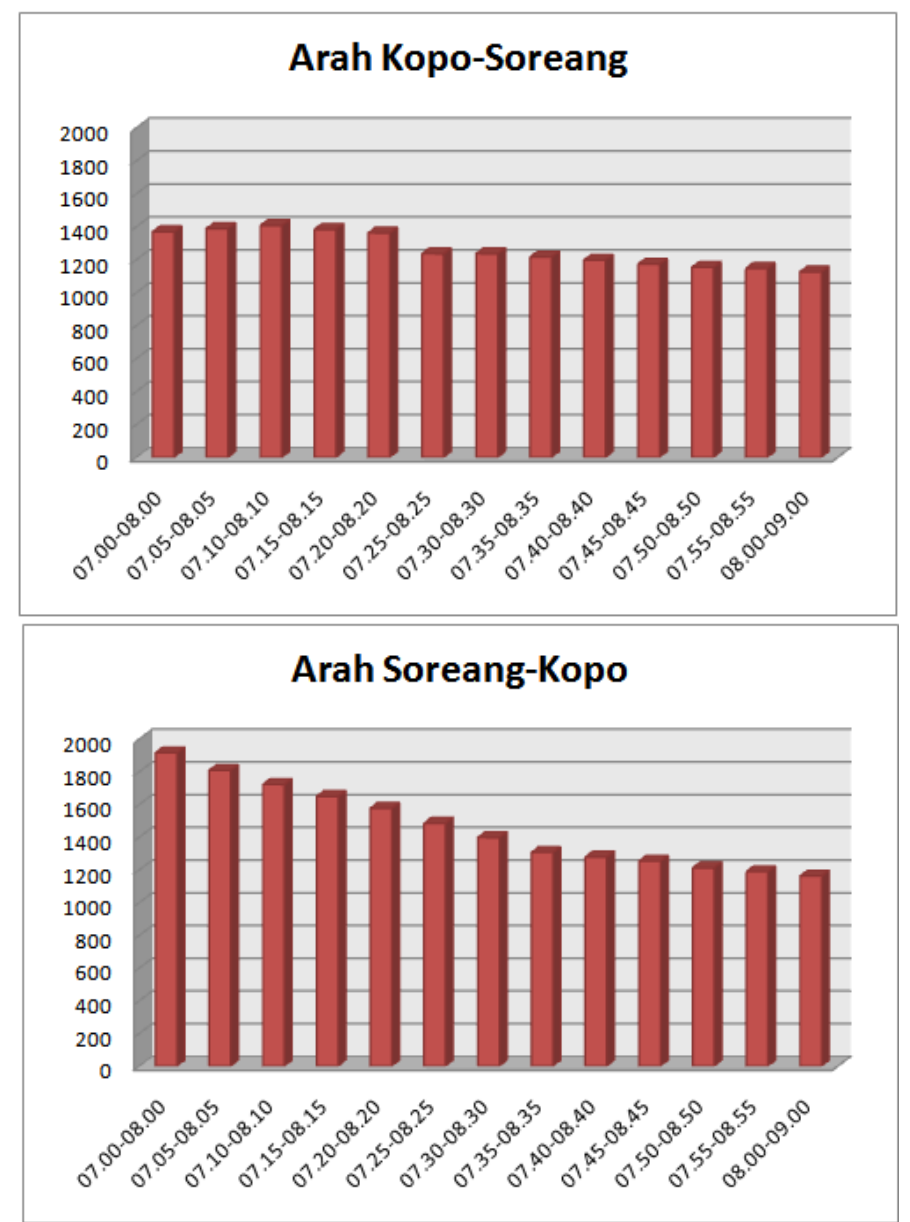

Gambar 3. Fluktuasi Volume Lalulintas Kendaraan Pagi Hari 
Berdasarkan Gambar 3 fluktuasi volume lalulintas yang terjadi di Jalan Terusan Kopo pagi hari pada lajur arah Kopo menuju Soreang diketahui bahwa volume lalulintas tertinggi adalah sebesar $1407.25 \mathrm{smp} / \mathrm{jam}$, sedangkan pada lajur arah Soreang menuju Kopo diketahui bahwa volume lalulintas tertinggi adalah sebesar $1915.1 \mathrm{smp} / \mathrm{jam}$.

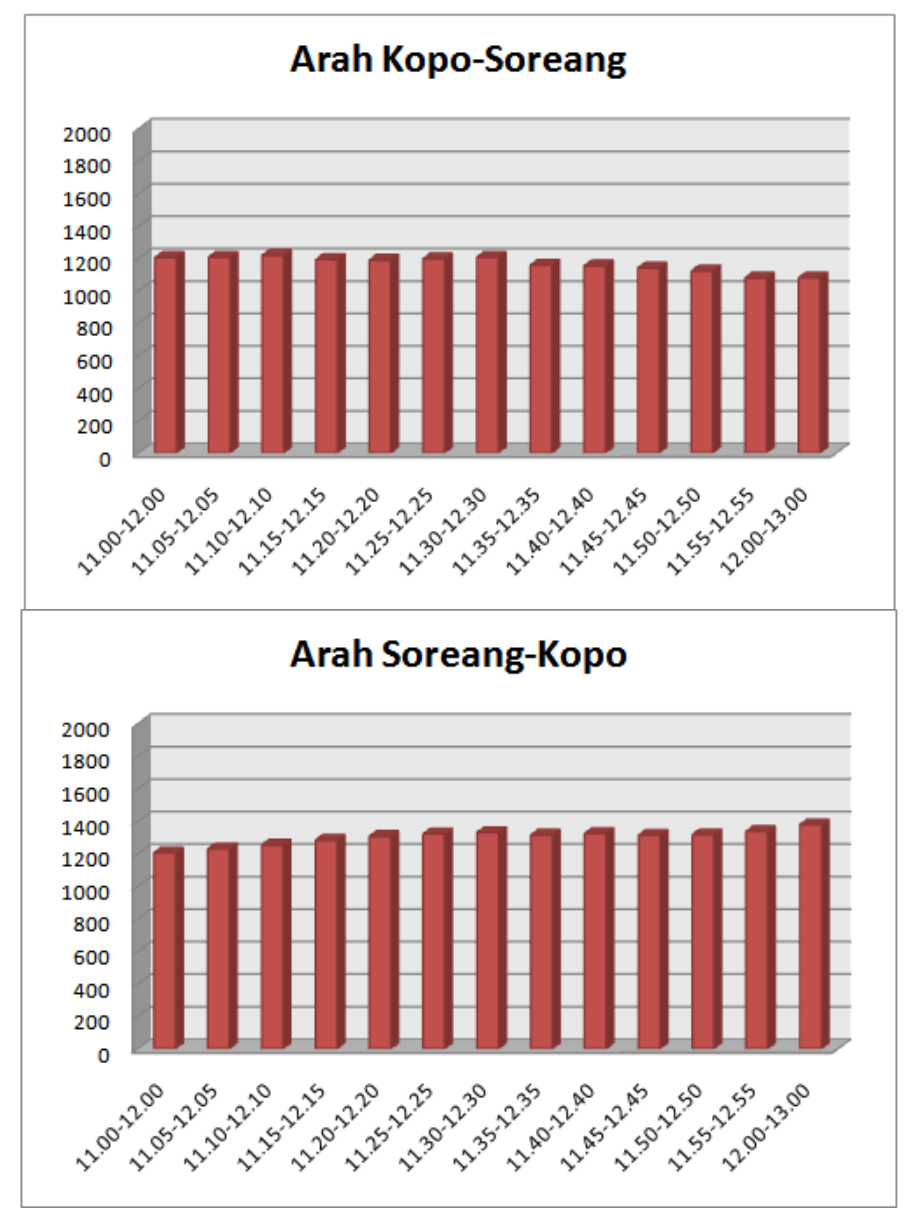

Gambar 4. Fluktuasi Volume Lalulintas Kendaraan Siang Hari

Berdasarkan Gambar 4 fluktuasi volume lalulintas yang terjadi di Jalan Terusan Kopo siang hari pada lajur arah Kopo menuju Soreang diketahui bahwa volume lalulintas tertinggi adalah sebesar $1217.95 \mathrm{smp} / \mathrm{jam}$, sedangkan pada lajur arah Soreang menuju Kopo diketahui bahwa volume lalulintas tertinggi sebesar $1378.75 \mathrm{smp} / \mathrm{jam}$. 


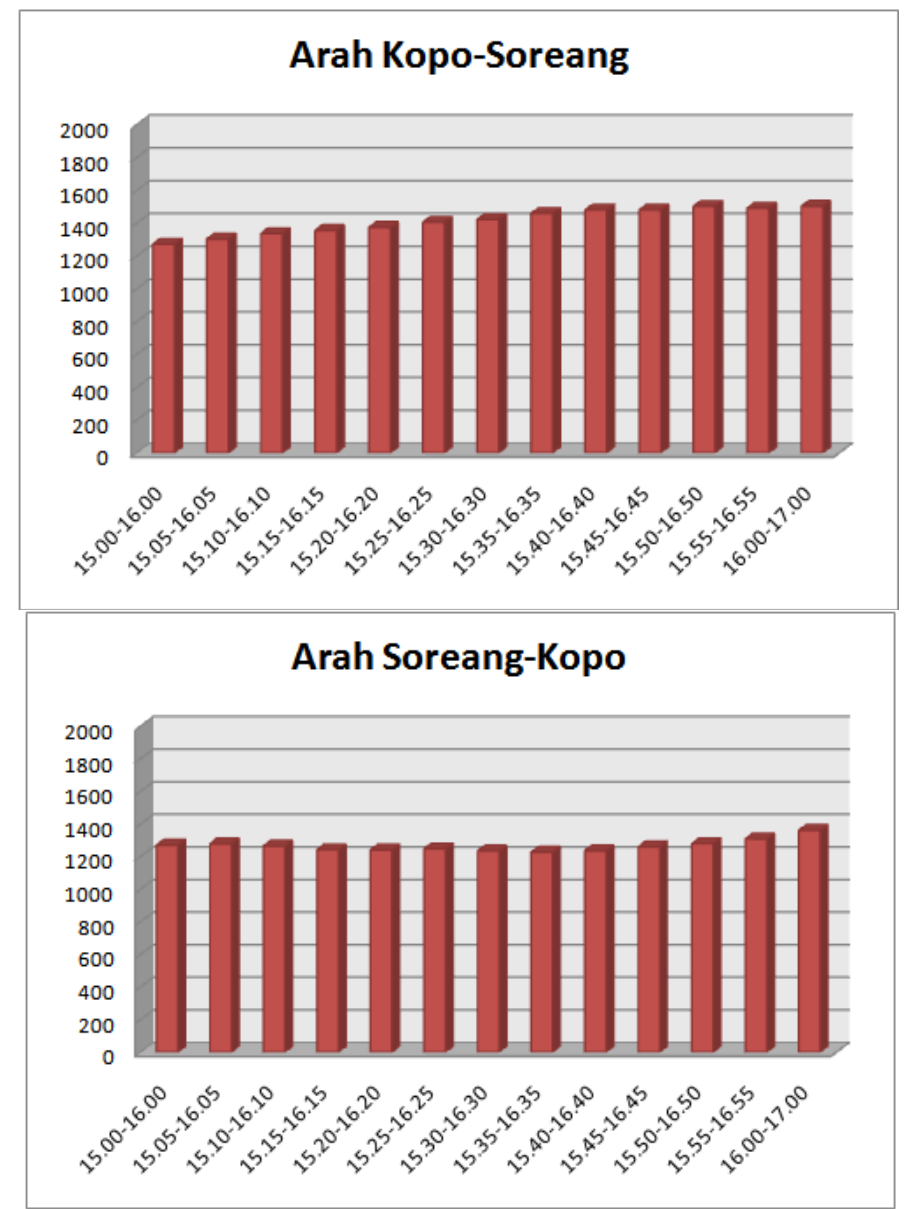

Gambar 5. Fluktuasi Volume Lalulintas Kendaraan Sore Hari

Berdasarkan Gambar 5 fluktuasi volume lalulintas yang terjadi di Jalan Terusan Kopo sore hari pada lajur arah Kopo menuju Soreang diketahui bahwa volume lalulintas tertinggi adalah sebesar $1503.70 \mathrm{smp} / \mathrm{jam}$, sedangkan pada lajur arah Soreang menuju Kopo diketahui bahwa volume lalulintas tertinggi sebesar $1361.20 \mathrm{smp} / \mathrm{jam}$.

\subsection{Analisis Kecepatan Lalulintas}

Kecepatan adalah perpindahan benda melalui suatu lintasan persatuan waktu dan dapat dinyatakan dalam $\mathrm{m} / \mathrm{det}$ atau $\mathrm{km} / \mathrm{jam}$. Kecepatan lalulintas sangat dipengaruhi oleh beberapa faktor seperti waktu, tempat, lingkungan dan perilaku dari pengemudi.

Dalam menganalisis kecepatan lalulintas yang terjadi maka variasi kecepatan rata - rata dari setiap jenis kendaraan yang ada tiap jam sangat penting untuk melihat fluktuasi yang terjadi. 


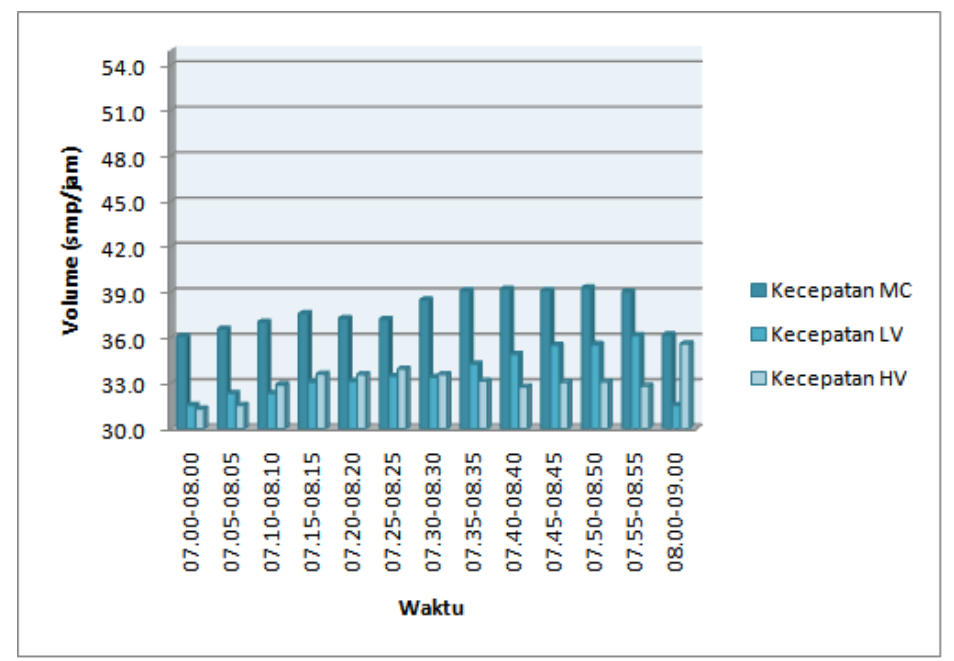

\section{Gambar 6. Fluktuasi Kecepatan Lalulintas Kendaraan Pagi Arah Kopo-Soreang}

Dari Gambar 6 diketahui fluktuasi kecepatan lalulintas yang terjadi di Jalan Terusan Kopo selama pagi hari dengan interval waktu 07.00 - 09.00 diketahui kecepatan rata - rata untuk sepeda motor (MC) berkisar 36,00 - 39,50 km/jam, kendaraan ringan (LV) berkisar 31,00 - 36,00 km/jam dan kendaraan berat (HV) berkisar 31,00-34,00 $\mathrm{km} / \mathrm{jam}$.

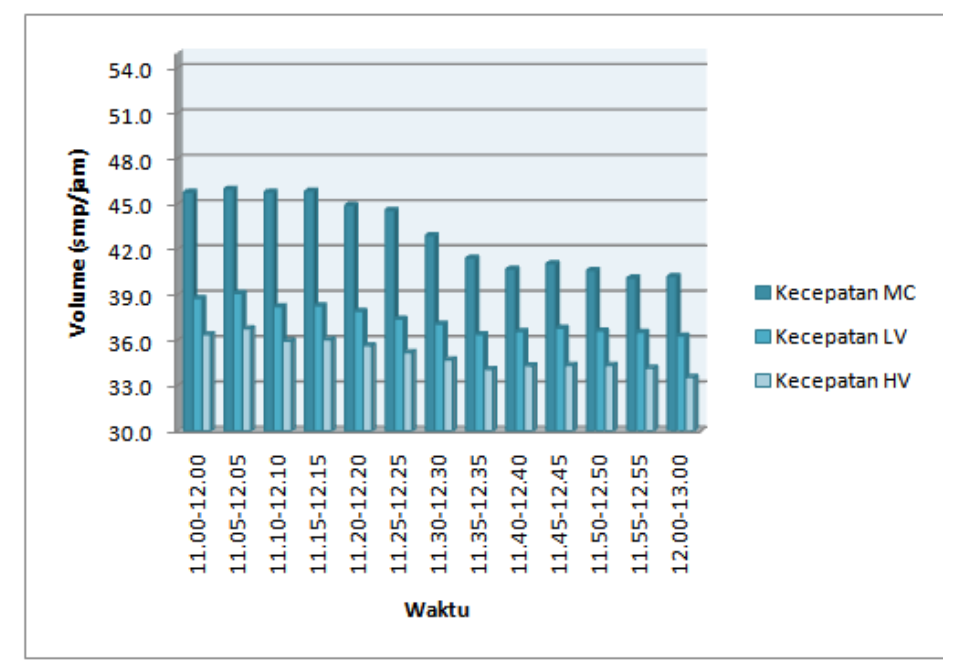

\section{Gambar 7. Fluktuasi Kecepatan Lalulintas Kendaraan Siang Arah Kopo-Soreang}

Dari Gambar 7 fluktuasi kecepatan lalulintas yang terjadi di Jalan Terusan Kopo selama siang hari dengan interval waktu 11.00 - 13.00 diketahui kecepatan rata - rata 
untuk sepeda motor (MC) berkisar 40,00 - 46,00 km/jam, kendaraan ringan (LV) berkisar $36,00-39,00 \mathrm{~km} / \mathrm{jam}$ dan kendaraan berat (HV) berkisar 33,00-37,00 km/jam.

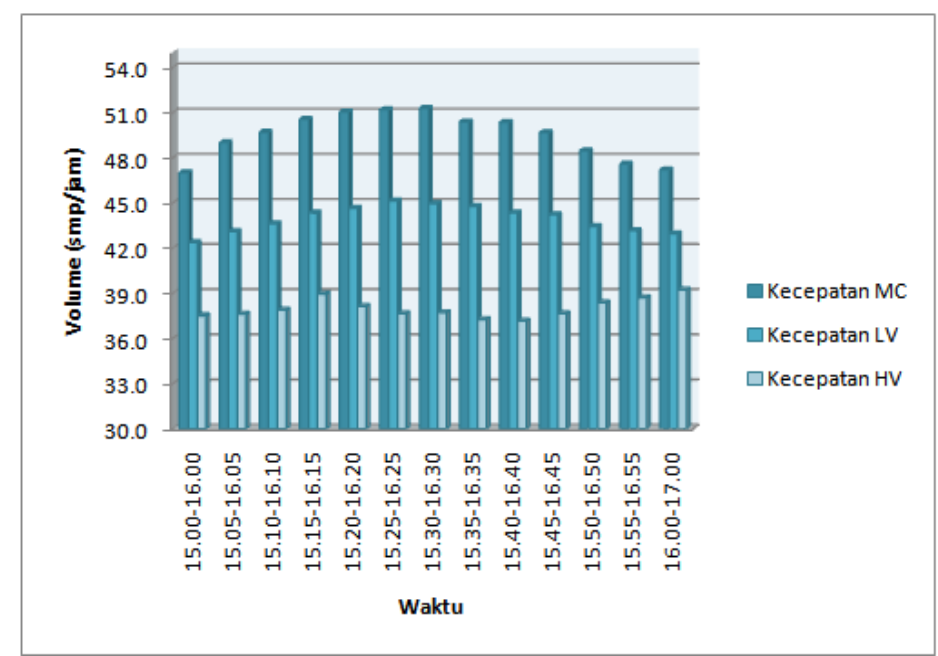

\section{Gambar 8. Fluktuasi Kecepatan Lalulintas Kendaraan Sore Arah Soreang-Kopo}

Dari Gambar 8 fluktuasi kecepatan lalulintas yang terjadi di Jalan Terusan Kopo selama sore hari dengan interval waktu 15.00 - 17.00 diketahui kecepatan rata - rata untuk sepeda motor (MC) berkisar 47,00 - 51,50 km/jam, kendaraan ringan (LV) berkisar $42,00-45,00 \mathrm{~km} / \mathrm{jam}$ dan kendaraan berat (HV) berkisar 37,00 - 39,00 km/jam.

\subsection{Analisis Kebisingan Lalulintas}

Berdasarkan hasil survei kebisingan lalulintas dengan menggunakan sound level meter di depan SDN Angkasa V Lanud Sulaiman, didapat data kebisingan lalulintas per jam. 


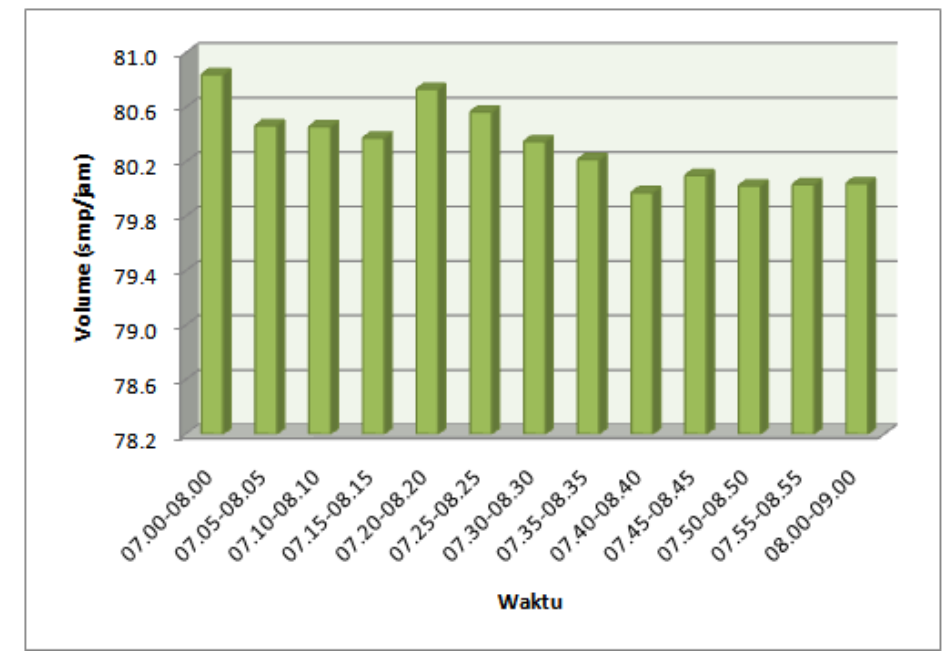

Gambar 9. Fluktuasi Kebisingan Lalulintas Pagi Hari

Dari Gambar 9 kebisingan lalulintas pada SDN Angkasa V Lanud Sulaiman terlihat bahwa kebisingan lalu lintas untuk periode pagi hari dengan interval waktu 07.00 - 09.00, kebisingan lalulintas berkisar antara 80,00-80,80 dB(A).

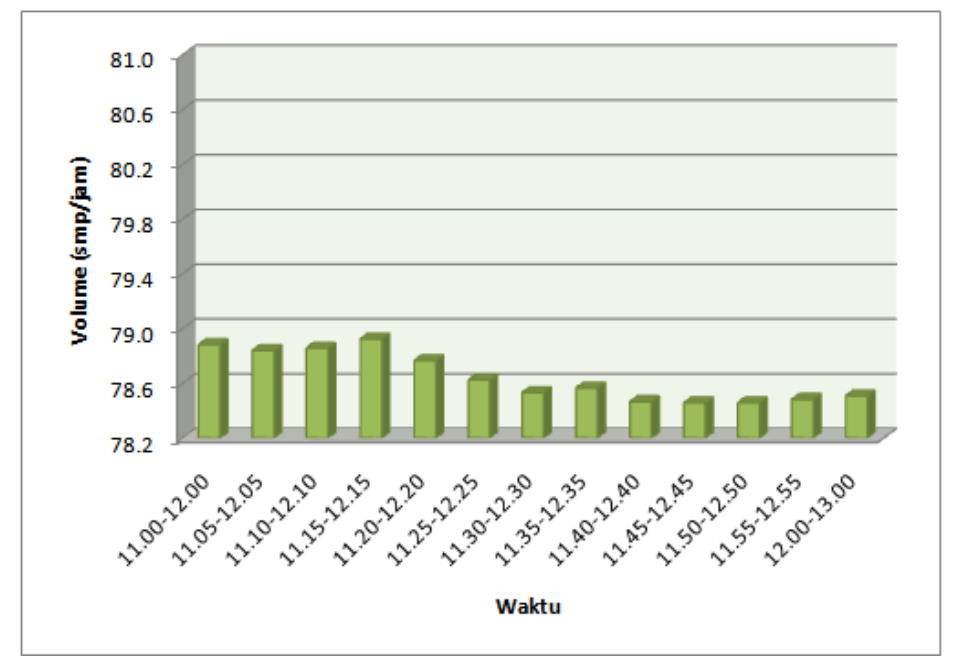

Gambar 10. Fluktuasi Kebisingan Lalulintas Siang Hari

Dari Gambar 10 kebisingan lalulintas pada SDN Angkasa V Lanud Sulaiman yang terletak di tepi Jalan Terusan Kopo terlihat bahwa kebisingan lalu lintas untuk periode siang hari dengan interval waktu 11.00 - 13.00, kebisingan lalulintas berkisar antara $78,50-79,00 \mathrm{~dB}(\mathrm{~A})$. 


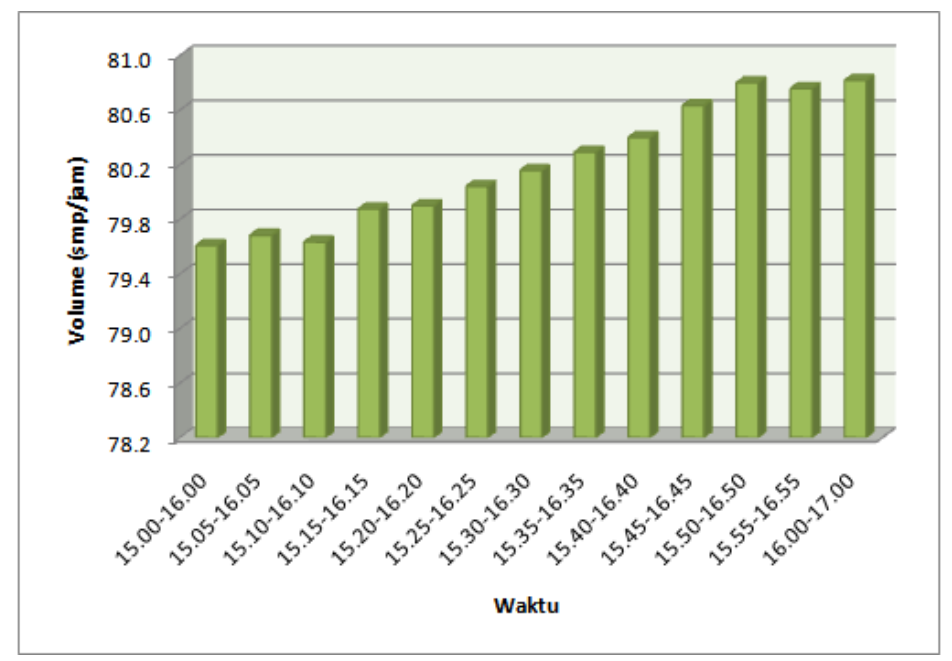

Gambar 11. Fluktuasi Kebisingan Lalulintas Sore Hari

Dari Gambar 11 kebisingan lalulintas pada SDN Angkasa V Lanud Sulaiman yang terletak di tepi Jalan Terusan Kopo terlihat bahwa kebisingan lalu lintas untuk periode sore hari dengan interval waktu 15.00 - 17.00, kebisingan lalulintas berkisar antara 79,50 - 80,80 $\mathrm{dB}(\mathrm{A})$, melebihi ambang batas yang dikeluarkan oleh Keputusan Kementrian Negara Lingkungan Hidup tahun 1996 yaitu 55 dB(A) untuk lokasi pendidikan dan U.S. Department of Transportation yaitu tidak melebihi $65 \mathrm{~dB}(\mathrm{~A})$.

\subsection{Pemodelan Kebisingan Lalulintas}

Data input yang digunakan untuk analisis regresi linier berganda adalah ratarata kebisingan lalulintas sebagai variabel dependent (Y), sedangkan untuk variabel independent yang terdiri dari volume sepeda motor $\left(\mathrm{X}_{1}\right)$, volume kendaraan ringan $\left(\mathrm{X}_{2}\right)$, volume kendaraan berat $\left(\mathrm{X}_{3}\right)$ dan kecepatan lalulintas rata-rata $\left(\mathrm{X}_{4}\right)$. Data input tersebut selanjutnya dianalisis dengan metode regresi linier berganda menggunakan bantuan Software SPSS versi 17.0 untuk memprediksi pengaruh dari volume lalulintas dan kecepatan lalulintas terhadap kebisingan lalulintas yang terjadi pada SDN Angkasa V Lanud Sulaiman yang terletak di tepi Jalan Terusan Kopo. Variabel dependent dan variabel-variabel independent disajikan dalam bentuk tabel yang dapat dilihat pada Tabel 3. 
Tabel 3. Data Input Model Regresi Linier

\begin{tabular}{|c|c|c|c|c|}
\hline $\begin{array}{c}\text { Kebisingan } \\
\mathrm{dB}(\mathrm{A})\end{array}$ & $\begin{array}{c}\text { Volume MC } \\
\text { Kend/jam }\end{array}$ & $\begin{array}{c}\text { Volume LV } \\
\text { Kend/jam }\end{array}$ & $\begin{array}{c}\text { Volume HV } \\
\text { Kend/jam }\end{array}$ & $\begin{array}{c}\text { Kecepatan Rata-rata } \\
\text { Km/jam }\end{array}$ \\
\hline $\mathbf{Y}$ & $\mathrm{X}_{1}$ & $\mathbf{X}_{2}$ & $\mathbf{X}_{3}$ & $X_{4}$ \\
\hline 80.8 & 2326 & 731 & 47 & 33 \\
\hline 80.5 & 2333 & 744 & 51 & 33,5 \\
\hline 80.5 & 2329 & 759 & 55 & 34,1 \\
\hline 80.4 & 2297 & 740 & 57 & 34,8 \\
\hline 80.7 & 2291 & 720 & 58 & 34,7 \\
\hline 80.6 & 2224 & 612 & 57 & 34,9 \\
\hline 80.4 & 2195 & 612 & 63 & 35,2 \\
\hline 80.2 & 2135 & 601 & 67 & 35,5 \\
\hline 80 & 2058 & 601 & 68 & 35,6 \\
\hline 80.1 & 2001 & 592 & 67 & 35,9 \\
\hline 80 & 1941 & 589 & 66 & 35,8 \\
\hline 80 & 1888 & 598 & 64 & 35,8 \\
\hline 80 & 1813 & 595 & 64 & 35,7 \\
\hline 78.9 & 1712 & 607 & 141 & 40,3 \\
\hline 78.8 & 1715 & 601 & 147 & 40,6 \\
\hline 78.9 & 1707 & 616 & 146 & 40 \\
\hline 78.9 & 1685 & 600 & 142 & 40,1 \\
\hline 78.8 & 1721 & 587 & 143 & 39,5 \\
\hline 78.6 & 1747 & 579 & 151 & 39,1 \\
\hline 78.5 & 1771 & 582 & 151 & 38,2 \\
\hline 78.6 & 1782 & 531 & 151 & 37,3 \\
\hline 78.5 & 1797 & 533 & 142 & 37,2 \\
\hline 78.5 & 1767 & 527 & 142 & 37,4 \\
\hline 78.5 & 1784 & 515 & 133 & 37,2 \\
\hline 78.5 & 1818 & 469 & 129 & 36,9 \\
\hline 78.5 & 1818 & 478 & 122 & 36,7 \\
\hline 79.6 & 2026 & 594 & 143 & 42,3 \\
\hline 79.7 & 2080 & 608 & 146 & 43,2 \\
\hline 79.6 & 2140 & 631 & 142 & 43,7 \\
\hline 79.9 & 2243 & 639 & 130 & 44,6 \\
\hline 79.9 & 2366 & 640 & 119 & 44,6 \\
\hline 80 & 2521 & 633 & 119 & 44,6 \\
\hline 80.2 & 2604 & 633 & 115 & 44,7 \\
\hline 80.3 & 2736 & 635 & 117 & 44,1 \\
\hline 80.4 & 2846 & 625 & 120 & 43,9 \\
\hline 80.6 & 3008 & 594 & 112 & 43,8 \\
\hline 80.8 & 3199 & 573 & 108 & 43,4 \\
\hline 80.8 & 3324 & 541 & 100 & 43,1 \\
\hline
\end{tabular}

Pemodelan Kebisingan Lalulintas Di Jalan Terusan Kopo Bandung 


\begin{tabular}{|c|c|c|c|c|}
\hline $\begin{array}{c}\text { Kebisingan } \\
\text { dB(A) }\end{array}$ & $\begin{array}{c}\text { Volume MC } \\
\text { Kend/jam }\end{array}$ & $\begin{array}{c}\text { Volume LV } \\
\text { Kend/jam }\end{array}$ & $\begin{array}{c}\text { Volume HV } \\
\text { Kend/jam }\end{array}$ & $\begin{array}{c}\text { Kecepatan Rata-rata } \\
\text { Km/jam }\end{array}$ \\
\hline 80.8 & 3470 & 521 & 96 & 43,1 \\
\hline
\end{tabular}

Berdasarkan Tabel 3 yang diproses menggunakan Software SPSS versi 17.0 diperoleh model hubungan regresi pengaruh variabel independent terhadap variabel dependent-nya adalah:

$$
Y=75,753+0,001 X_{1}+0,002 X_{2}-0,018 X_{3}+0,082 X_{4}
$$

$$
\begin{aligned}
\text { Dimana } \mathrm{Y} & =\text { Kebisingan lalulintas }(\mathrm{dB}(\mathrm{A})) \\
\mathrm{X}_{1} & =\text { Volume MC }(\mathrm{kend} / \mathrm{jam}) \\
\mathrm{X}_{2} & =\text { Volume LV }(\mathrm{kend} / \mathrm{jam}) \\
\mathrm{X}_{3} & =\text { Volume HV }(\mathrm{kend} / \mathrm{jam}) \\
\mathrm{X}_{4} & =\text { Kecepatan lalulintas }(\mathrm{km} / \mathrm{jam})
\end{aligned}
$$

Model hubungan regresi di atas belum merupakan model terbaik, karena nilai koefisien dari variabel $\mathrm{X}_{3}$ bernilai negatif. Hal ini menunjukkan bahwa variabel $\mathrm{X}_{3}$ banding terbalik dengan variabel $\mathrm{Y}$, sedangkan variabel $\mathrm{X}_{1}, \mathrm{X}_{2}$ dan $\mathrm{X}_{4}$ berbanding lurus dengan variabel $\mathrm{Y}$.

Dengan kata lain pada saat volume HV menurun maka kebisingan lalulintas akan meningkat dan berlaku juga untuk kondisi sebaliknya. Namun, secara logika volume kendaraan terhadap kebisingan adalah berbanding lurus dan juga presentase volume kendaraan berat sangat berpengaruh terhadap penaksiran tingkat kebisingan dasar.

Oleh karena itu, untuk memperoleh model hubungan regresi yang baik adalah dengan menggunakan stepwise method pada analisis dengan menggunakan Software SPSS versi 17.0. Dengan menggunakan stepwise method diperoleh model hubungan regresi:

$$
Y=73,642+0,001 X_{1}+0,006 X_{2}
$$

$$
\begin{aligned}
\operatorname{Dimana} \mathrm{Y} & =\text { Kebisingan lalulintas }(\mathrm{dB}(\mathrm{A})) \\
\mathrm{X}_{1} & =\text { Volume MC }(\text { kend } / \mathrm{jam}) \\
\mathrm{X}_{2} & =\text { Volume LV }(\text { kend } / \mathrm{jam})
\end{aligned}
$$


Baik tidaknya suatu model regresi linier berganda dalam mengestimasi variabel terikat dengan terhadap variabel bebasnya juga dapat diketahui dengan melihat tiga parameter, yaitu koefisien determinasi $\left(\mathrm{R}^{2}\right)$, nilai $\mathrm{F}$ dan nilai t. Dari hasil analisis menggunakan SPSS versi 17.0 dijelaskan sebagai berikut:

1. Koefisien determinasi

\section{Tabel 4. Koefisien Determinasi}

\begin{tabular}{|c|c|c|c|c|}
\hline Model & $\mathrm{R}$ & R Square & Adjusted R Square & Std. Error of the Estimate \\
\hline 1 & $.893^{\mathrm{a}}$ & .797 & .786 & .38505 \\
\hline
\end{tabular}

Dari Tabel 4 diketahui bahwa nilai adjusted $R^{2}$ adalah 0,786 hal ini berarti bahwa 78,6\% variasi kebisingan (Y) dapat dijelaskan oleh kedua variasi variabel independent-nya yaitu volume $\mathrm{MC}\left(\mathrm{X}_{1}\right)$ dan volume LV $\left(\mathrm{X}_{2}\right)$. Sedangkan sisanya sebesar 21,4\% dijelaskan oleh sebab-sebab diluar model. Standard Error of the Estimate (SEE) sebesar 0,38505 menjelaskan bahwa semakin kecil nilai SEE akan membuat model regresi semakin tepat dalam memprediksi variabel terikatnya.

2. Uji Anova

Tabel 5. Uji Anova

\begin{tabular}{|cc|c|c|c|c|c|}
\hline \multicolumn{1}{|c|}{ Model } & Sum of Squares & df & Mean Square & F & Sig. \\
\hline 1 & Regression & 21.017 & 2 & 10.508 & 70.877 & $.000^{\mathrm{b}}$ \\
& Residual & 5.338 & 36 & .148 & & \\
& Total & 26.354 & 38 & & & \\
\hline
\end{tabular}

Hipotesis:

Ho: $\mu=\mu_{0}$

Ha: $\mu \neq \mu_{0}$

Pengambilan keputusan:

Jika nilai signifikansi $\leq 0,05$ maka Ho diterima Ha ditolak

Jika nilai signifikansi $>0,05$ maka Ho ditolak Ha diterima

Dari uji Anova atau F test pada Tabel 5 didapat nilai $\mathrm{F}$ hitung sebesar 70,877 dengan signifikansi 0,000. Nilai signifikansi tersebut jauh lebih kecil dari 
nilai probabilitas 0,05 maka Ho diterima dan Ha ditolak. Dengan begitu model regresi dapat digunakan untuk memprediksi kebisingan.

3. Uji t

Tabel 6. Uji t

\begin{tabular}{|ll|r|r|r|r|r|}
\hline \multirow{2}{*}{ Model } & & \multicolumn{2}{|c|}{ Unstandardized Coefficients } & \multicolumn{2}{|c|}{$\begin{array}{c}\text { Standardized } \\
\text { Coefficients }\end{array}$} & \multicolumn{2}{|c|}{} \\
\cline { 2 - 7 } & & \multicolumn{1}{|c|}{$\mathrm{B}$} & \multicolumn{1}{|c|}{ Std. Error } & \multicolumn{1}{c|}{ Beta } & \multicolumn{1}{c|}{ Sig. } \\
\hline 1 & (Constant) & 73.642 & .602 & & 122.343 & .000 \\
& X1 & .001 & .000 & .704 & 9.266 & .000 \\
& X2 & .006 & .001 & .451 & 5.944 & .000 \\
\hline
\end{tabular}

Hipotesis:

Ho: $\mu=\mu_{0}$

Ha: $\mu \neq \mu_{0}$

Pengambilan keputusan:

Jika nilai signifikansi $\leq 0,05$ maka Ho diterima Ha ditolak

Jika nilai signifikansi $>0,05$ maka Ho ditolak Ha diterima

Dari Tabel 6 kedua variabel independent yang dimasukkan kedalam model regresi variabel $X_{1}$ hingga $X_{2}$ dengan nilai signifikansi 0,000 jauh lebih kecil 0,05 maka Ho diterima Ha ditolak. Secara statistik dapat dilihat bahwa model regresi linier yang telah diperoleh menunjukkan kedua variabel tersebut berpengaruh terhadap kebisingan. Dari nilai standardized coefficients untuk $\mathrm{X}_{1}$ (volume MC) sebesar 70,4\% dan $\mathrm{X}_{2}$ (volume LV) sebesar 40,1\% berpengaruh terhadap kebisingan lalulintas di Jalan Terusan Kopo Bandung.

Untuk nilai koefisien dari variabel $\mathrm{X}_{1}$ dan $\mathrm{X}_{2}$ bernilai positif maka kedua variabel tersebut berbanding lurus dengan variabel $\mathrm{Y}$, dengan kata lain volume apabila sepeda motor dan volume kendaraan meningkat maka kebisingan juga akan meningkat, dan sebaliknya.

\section{KESIMPULAN DAN SARAN}

\subsection{Kesimpulan}

Dari hasil pengolahan, analisis dan pembahasan dapat disusun kesimpulan sebagai berikut : 
1. Volume lalulintas yang terjadi pada Jalan Terusan Kopo adalah pada pagi hari sebesar 3322,35 smp/jam, pada siang hari sebesar 2596,7 smp/jam dan pada sore hari sebesar 2864,9 smp/jam.

2. Kecepatan rata - rata lalulintas yang terjadi di Jalan terusan kopo adalah $36,00-$ $51,50 \mathrm{~km} / \mathrm{jam}$ untuk sepeda motor (MC), 31,00 - 45,00 km/jam untuk kendaraan ringan (LV) dan $31,00-39,00 \mathrm{~km} / \mathrm{jam}$ untuk kendaraan berat (HV).

3. Kebisingan lalulintas terjadi selama pengamatan adalah berkisar antara 78,5080,80 dB(A), melebihi ambang batas yang dikeluarkan oleh Keputusan Kementrian Negara Lingkungan Hidup tahun 1996 yaitu 55 dB(A) untuk lokasi pendidikan dan U.S. Department of Transportation yaitu tidak melebihi $65 \mathrm{~dB}(\mathrm{~A})$.

4. Pemodelan kebisingan lalulintas di Jalan Terusan Kopo Bandung yang lebih baik dan logis merupakan hasil stepwise method $\left(\mathrm{Y}=73,642+0,001 \mathrm{X}_{1}+0,006 \mathrm{X}_{2}\right)$, dimana yang berpengaruh paling besar terhadap kebisingan lalulintas adalah volume sepeda motor sebesar $70,4 \%$.

\subsection{Saran}

Berdasarkan hasil studi yang dilakukan maka ada beberapa saran untuk memperoleh pemodelan yang lebih baik, yaitu :

1. Diperlukan penelitian lebih lanjut mengenai hubungan antara kebisingan dengan volume dan kecepatan lalulintas dalam waktu survei yang lebih lama (beberapa hari) sehingga dapat melihat fluktuasi yang terjadi. Dengan waktu survei selama beberapa hari maka akan didapat beberapa model regresi sehingga dapat menghasilkan pemodelan yang paling baik pada lokasi yang ditinjau, maka pemodelan dapat digunakan untuk memprediksi kebisingan lalulintas.

2. Pemilihan lokasi pengamatan yang bervariasi misalnya suatu jalan yang memiliki kecepatan lalulintas diatas $40 \mathrm{~km} / \mathrm{jam}$ misalnya jalan tol dengan tujuan sumber kebisingan yang diukur murni dari kendaraan saja.

\section{DAFTAR PUSTAKA}

1. Ali N., Liputo A., 2009, Studi Kebisingan Lalu Lintas Pada Ruas Jalan Urip Sumiharjo Jurnal Simposium XII FSTPT, Makassar, pp 399-410.

2. Cohn, Louis F., Mcvoy, Gray R., Environmental Analysis of Transportation Systems, John Wiley \& Sons, Inc., New York.

Pemodelan Kebisingan Lalulintas Di Jalan Terusan Kopo Bandung (Nyayu Luthfia Sya'bani, Budi Hartanto Susilo) 
3. Department of Transport Welsh Office, 1988, Calculation of Road Traaffic Noise, Her Majesty's Stationery Office, London.

4. Departemen Permukiman dan Prasarana Wilayah (Depkimpraswil), 2005, Pedoman Mitigasi Dampak Kebisingan Akibat Lalu Lintas Jalan (Pt-T-16-2005B), Jakarta.

5. Handayani Dini, 2007, Pengkajian Faktor-Faktor Tingkat Kebisingan Jalan Perkotaan, Jurnal Puslitbang Jalan dan Jembatan, Bandung.

6. Kementerian Negara Lingkungan Hidup, 1996, Baku Tingkat Kebisingan, Surat Keputusan Menteri Negara Lingkungan Hidup No.48/MENLH/1996/25, Jakarta.

7. Susilo, B.H., 1998, Sistem Transportasi, Penerbit Gunadarma, Jakarta.

8. Susilo, B.H., 2009, Rekayasa Lalu Lintas, Penerbit Trisakti, Jakarta.

9. Walpole, R.E. dan R.H. Mayers, 1995, Ilmu Peluang dan Statistika untuk Insyinyur dan Ilmuwan, Edisi ke-4, ITB, Bandung.

10.Wardhana, W.A., 2001, Dampak Pencemaran Lingkungan, Andi Offset, Jakarta.

11.Watkins L.H., 1981, Environmental Impact of Roads and Traffic, Applied Science Publishers, London.

\section{LAMPIRAN}

Lampiran 1 Data Input Model Regresi Linier

\begin{tabular}{|c|c|c|c|c|}
\hline $\begin{array}{c}\text { Kebisingan } \\
\text { dB(A) }\end{array}$ & $\begin{array}{c}\text { Volume MC } \\
\text { Kend/jam }\end{array}$ & $\begin{array}{c}\text { Volume LV } \\
\text { Kend/jam }\end{array}$ & $\begin{array}{c}\text { Volume } \\
\text { HV } \\
\text { Kend/jam }\end{array}$ & $\begin{array}{c}\text { Kecepatan Rata- } \\
\text { rata } \\
\text { Km/jam }\end{array}$ \\
\hline $\mathbf{Y}$ & $\mathbf{X}_{\mathbf{1}}$ & $\mathbf{X}_{\mathbf{2}}$ & $\mathbf{X}_{\mathbf{3}}$ & $\mathbf{X}_{\mathbf{4}}$ \\
\hline 80.8 & 2326 & 731 & 47 & 33 \\
\hline 80.5 & 2333 & 744 & 51 & 33,5 \\
\hline 80.5 & 2329 & 759 & 55 & 34,1 \\
\hline 80.4 & 2297 & 740 & 57 & 34,8 \\
\hline 80.7 & 2291 & 720 & 58 & 34,7 \\
\hline 80.6 & 2224 & 612 & 57 & 34,9 \\
\hline 80.4 & 2195 & 612 & 63 & 35,2 \\
\hline 80.2 & 2135 & 601 & 67 & 35,5 \\
\hline 80 & 2058 & 601 & 68 & 35,6 \\
\hline 80.1 & 2001 & 592 & 67 & 35,9 \\
\hline
\end{tabular}




\begin{tabular}{|c|c|c|c|c|}
\hline $\begin{array}{c}\text { Kebisingan } \\
\text { dB(A) }\end{array}$ & $\begin{array}{c}\text { Volume MC } \\
\text { Kend/jam }\end{array}$ & $\begin{array}{c}\text { Volume LV } \\
\text { Kend/jam }\end{array}$ & $\begin{array}{c}\text { Volume } \\
\text { HV } \\
\text { Kend/jam }\end{array}$ & $\begin{array}{c}\text { Kecepatan Rata- } \\
\text { rata } \\
\text { Km/jam }\end{array}$ \\
\hline 80 & 1941 & 589 & 66 & 35,8 \\
\hline 80 & 1888 & 598 & 64 & 35,8 \\
\hline 80 & 1813 & 595 & 64 & 35,7 \\
\hline 78.9 & 1712 & 607 & 141 & 40,3 \\
\hline 78.8 & 1715 & 601 & 147 & 40,6 \\
\hline 78.9 & 1707 & 616 & 146 & 40 \\
\hline 78.9 & 1685 & 600 & 142 & 40,1 \\
\hline 78.8 & 1721 & 587 & 143 & 39,5 \\
\hline 78.6 & 1747 & 579 & 151 & 39,1 \\
\hline
\end{tabular}

